\title{
The Structure of the Wage Gap for Temporary Workers: Evidence from Australian Panel Data $\underline{\text { TITLE }}$
}

The Structure of the Wage Gap for Temporary Workers: Evidence from Australian Panel Data

RUNNING TITLE

The Wage Gap for Temporary Workers

$\underline{\text { AUTHORS / AFFLIATIONS }}$

Inga Lass

Melbourne Institute of Applied Economic and Social Research, University of Melbourne

Mark Wooden

Melbourne Institute of Applied Economic and Social Research, University of Melbourne;

\section{$\underline{\text { ACKNOWLEDGEMENTS }}$}

This paperuses confidentialised unit record file data from the Household, Income and Labour Dynamics in Australia (HILDA) Survey. The HILDA Survey Project was initiated and funded by the Australian Government Department of Social Services (DSS) and is managed by the Melbourne-Institute of Applied Economic and Social Research. This research was also supported under the Australian Research Council's Discovery Projects funding scheme (project\#DP160103171).

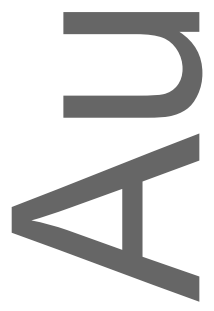

This is the author manuscript accepted for publication and has undergone full peer review but has not been through the copyediting, typesetting, pagination and proofreading process, which may lead to differences between this version and the Version of Record. Please cite this article as doi: 10.1111/bjir.12458.

This article is protected by copyright. All rights reserved. 


\section{Abstract}

This study uses panel data for Australia to estimate the wage differential between workers in temporary jobs and workers in permanent jobs. It is the first study to use unconditional quantile regression methods in combination with fixed effects to examine how this gap varies over the entire wage distribution. While the wages of fixed-term contract workers are found to be similar to those of permanent workers, low-paid casual workers experience a wage penalty and high-paid casual workers a wage premium compared to their permanent counterparts. Temporary agency workers also usually receive a wage premium, which is particularly large for the most well paid.

\section{Keywords}

Casual employment; Temporary employment; HILDA Survey; Longitudinal data; Quantile regression; Wages

Word count (not including Abstract / Keywords) $=10,092$ 


\section{Introduction}

In recent decades, many Western countries have seen an increase in the incidence of temporary forms of employment, triggering a debate about the extent to which these forms of employment are inferior to permanent employment (e.g., Gash and McGinnity 2006; Giesecke and Groß 2003; Kalleberg et al. 2000; Watson 2005). An aspect that has attracted considerable attention is the wages temporary workers receive, with previous studies consistently finding a wage gap between permanent and temporary jobs. This wage gap has generally been interpreted as a disadvantage for temporary workers rooted in their type of contract, rather than a consequence of lower skills and abilities.

In this analysis, we use longitudinal data from Australia to provide new insights into the link between temporary employment and wages. We improve on existing research by employing unconditional quantile regressions with fixed effects, allowing assessment of the wage gap at all points along the wage distribution while also controlling for time-invariant unobserved heterogeneity. The latter is of large importance given the expectation that workers may select into job types based on unobserved eharaeteristics relating to productivity, and thus estimates of wage differences that do not account for these characteristics will be biased. We also do not treat temporary workers as a uniform group, but instead compare the structure of the wage gap for different types of temporary workers. More specifically, we analyse the wage outcomes of workers employed on fixed-term contracts (i.e., contracts that specify a date or event when employment will be terminated), on a casual basis (the main characteristic of which is the absence of any advance commitment by the employer to both the continuity of employment and the number of days or hours to be worked), and through a temporary employment agency (where the employer - i.e., the agency - acts as an intermediary between the worker and the firm for which the labour services are provided).

Australia is of interest, both because the temporary employment share is very high, and, unlike most other Western countries, it is casual work, and not fixed-term contracts, that is the most prevalent form of temporary employment. Data from the Household, Income and Labour Dynamics in Australia (HILDA) Survey indicate that in 2015 around 33\% of Australian employees were employed on a temporary contract, but with casual workers representing the majority $(70 \%)$. This incidence of temporary employment is far higher than in any other Western country and well above the OECD average of only $11 \%$ (based on data from the OECD.stat website).

International comparisons, however, are not straightforward, with most data collections treating temporary employment as synonymous with fixed-term contracts. Unlike Australia, in most countries this is not unreasonable given the absence of legislative mechanisms for hiring casual employees. Nevertheless, casual working does exist in other countries, sometimes under the label of zero-hours contracts, with survey data showing that casual workers accounted for between $5 \%$ and $8 \%$ of employees in Finland, the Netherlands, Spain, Switzerland and the UK in 2001 (International Labour Office 2004). Casual employment is thus of importance (and possibly growing importance) in other Western countries. The experience of Australia, with its extensive regulatory supports for casual employment, may provide insights about the consequences of possible policy reactions to such developments.

\section{State of research}

As already noted, a widely accepted finding is that workers employed on temporary contracts are paid less than permanent workers. The OECD (2015), for example, reports on data for 21 countries that show hourly wages for temporary employees ranging from $60 \%$ to $90 \%$ of the median hourly wages of permanent full-time employees. More importantly, while these wage gaps narrow once other

This article is protected by copyright. All rights reserved. 
worker characteristics are controlled for, they mostly remain reasonably large and significant. A notable exception here is Australia, with the estimated wage penalty attached to temporary employment (defined as either casual or fixed-term contract employment) just 2 to $3 \%$ in crosssectionatregression analyses, and zero in fixed-effects panel regressions.

The absenee of any sizeable wage penalty for casual work in Australia should not be surprising. Indeed, more surprising is that a sizeable wage premium is not found. This is because Australian industrial law provides for the payment to casual employees of a loading on top of their regular wage rate. But despite this regulatory requirement, previous studies have generally reported that casual employment in Australia is associated with, at most, a very modest wage premium (Green et al. 2010; Green and Leeves 2013; Watson 2005; Wooden 2001b). Australian research has also found evidence of a small wage premium for temporary agency workers, but no wage difference between fixed-term contract and permanent workers (Green et al. 2010; Watson 2005).

A major shorteoming of previous Australian studies is that they are focused on the mean of the wage distribution. Evidence from other countries, however, tells us that the wage effects of temporary employment may-differ between low- and high-paid workers (Bosio 2009, 2014; Comi and Grasseni 2012; Mertens et al 2007; Mertens and McGinnity 2005; Santangelo 2011). These studies usually find a relatively large wage penalty for temporary workers at the bottom of the wage distribution, which then shrinks as we proceed towards the top of the distribution.

International research, however, also has shortcomings. First, previous studies on the effect of temporary employment on wages at different points in the distribution have estimated cross-section models, and hence results might be biased due to unobserved heterogeneity. Second, with the exceptions of Bosio (2014) and Santangelo (2011), previous studies have estimated conditional quantile regression models where the definition of the quantiles depends on the independent variables in the models. In contrast, in unconditional quantile regression the quantiles are determined preregression, rendering results comparable across models with varying numbers of covariates.

The present study seeks to improve on the weaknesses identified above. Longitudinal data from the HILDA Survey are used to estimate quantile regressions of hourly wage outcomes where the key explanatory variable identifies the contractual status of the worker. In contrast to most international research, four different contract types are compared. Further, unconditional quantile regression models with fixed effects are estimated, thus solving the problem of shifting conditional distributions upon the inclusion of covariates and accounting for unobserved time-invariant heterogeneity.

\section{Theoretical considerations}

The usual starting point when thinking about wage gaps between temporary and permanent workers is the theory of compensating wage differentials (Rosen 1986), which predicts that different working conditions for workers with the same level of competence should result in a wage premium for those workers with less favourable conditions. Temporary workers should, therefore, be compensated with higher wages given the shorter job tenure (and hence lesser job security) inherent in their contracts. But as already noted, empirical research typically finds that temporary workers receive a wage penalty.

There-are several potential explanations for this wage penalty. Most importantly, differences in firing costs and replaceability between workers on different types of contracts mean that even otherwise identical workers within the same firm might be paid differently. Sørensen's Theory of Closed Positions (Sørensen 1983), for example, distinguishes, at the extreme, between closed positions, which can only be reassigned if the incumbent leaves voluntarily and are thus shielded from 
competition, and open positions, where the cost of firing is zero and that therefore can be abolished or the worker replaced at any time. Permanent jobs can be described as relatively closed positions and temporary jobs as relatively open positions (Giesecke and Gross 2004). Related concepts have also been put forward in economics. For example, both the insider-outsider model (e.g., Bentolila and Dolado 1994; Lindbeck and Snower 2001) and the buffer stock model (e.g., Atkinson 1984; Booth et al. 2002a) suggest that firms with a stable core of permanent workers will also employ a group of temporary workers who can easily be laid off if demand declines. Due to their greater job security, permanent workers are in a better position to bargain for higher wages or to lower their productivity while retaining the same wage. The bargaining power of permanent workers is further enhanced by the tendency for unions to better represent the interests of permanent workers (Campbell 1996; Gumbrell-McCormick 2011).

Over time, temporary workers may also become less productive than comparable permanent workers. Since workers in temporary jobs have relatively short expected job tenures at time of hire, the incentive to inyest in training will be low for both employers and workers. Empirical research mostly reports evidence that is consistent with this hypothesis (Booth et al. 2002b; Draca and Green 2004; Nienhüser and Matiaske 2006). This relative lack of access to, and interest in, training opportunities is expected to lead to a productivity gap between temporary and permanent workers, which in turn will be reflected in wage differences.

Other explanations revolve around the notion of temporary employment as a form of investment on the part of workers. First, employers may use temporary jobs as probationary or screening devices given uncertainty about workers' abilities (Faccini 2014). And indeed, studies in both the UK and Germany have reported evidence of relatively large fractions of fixed-term contract workers subsequently receiving a permanent contract with the same employer (Boockmann and Hagen 2005; Booth et al. 2002b). Workers may be willing to accept lower wages during the probationary period given the prospect of a permanent contract. Second, temporary work might allow workers to accumulate a greater variety of labour market experiences. For example, temporary jobs may be part of a search process during which workers gradually learn about which types of jobs best suit their skills and interests (Booth et al. 2002b).

It has also been argued that a focus on wages within a compensating differentials framework is too narrow, as workers value a broad range of job characteristics besides wages and job security (Daw and Hardie 2012). In particular, some workers may select into temporary jobs because they place more weight on flexible work arrangements than on high wages.

Predictions about the existence of a wage penalty or premium for temporary workers are thus not straightforward. Any compensating wage differential for temporary employment might be counterbalanced by wage losses due to relatively low bargaining power and productivity, preferences for other types of benefits, and the investment nature of temporary jobs.

There are also reasons to believe these forces do not apply uniformly across the wage distribution. First, the reasons why employers hire temporary workers differ between low-paid and high-paid jobs. Accommodating fluctuations in demand via temporary workers is more likely in low-skilled jobs with easy measurement of productivity and little need for firm-specific human capital (Mertens et al. 2007; Mertens and McGinnity 2005). Second, given the union wage premium is larger for low-paid than high-paid-workers (Cai and Liu 2008; Schmitt 2008), it follows that the role of unions in widening the wage gap between permanent and temporary workers is also larger among low-paid workers (Bosio 2014; Comi and Grasseni 2012). Bargaining for compensating wage differentials also presupposes that workers can choose between two jobs, instead of between a temporary job and unemployment (Mertens et al. 2007). Low-paid temporary workers, however, can be expected to have fewer job 
alternatives than high-paid temporary workers, reflecting their relative lack of skills, which in turn is reflected in greater risk of job loss and unemployment. Due to the low bargaining power of low-paid temporary workers, we also expect a relatively high degree of non-compliance with wage legislation among employers of these workers.

In contrast, high-paid temporary workers will usually be highly skilled and have more alternative job offers and thus relatively high bargaining power. They can be expected to seek and accept temporary positions only if there is a premium attached to it, rendering compensating wage differentials more likely at this end of the wage distribution (Mertens and McGinnity 2005). Employers, in turn, will be likely to hire high-skilled temporary workers to meet a short-term or sudden demand for specific skills, rather than to build a buffer stock of easily dismissible workers. This argument applies particularly to temporary agency workers given this form of employment enables employers to quickly access specialist expertise. In contrast, the wage premium for highskilled fixed-term contract workers might be lower, if not completely absent: In some high-skilled occupations, fixed-term contracts are part of a normal career path and should not be associated with any wage differential (Mertens and McGinnity 2005).

In summary, there are contradictory arguments about the sign of the wage gap for temporary workers. When looking across the wage distribution, however, the arguments presented suggest wage penalties for temporary workers at the bottom of the distribution and wage premiums for those at the top are mostlikely.

\section{The Australian context}

Labour market institutions affect the degree to which wages of permanent and different types of temporary workers differ. Most important are employment laws, which determine obligations and rights of employers and employees, and the associated institutions for handling conflict in workplaces and providing improvements in wages and other employment conditions. Other relevant institutions include trade unions, employer associations, and income support systems.

In general, Australian wages are highly regulated. Key elements include a comparatively high national minimum wage and a wide range of minimum wages for job classifications, prescribed in "awards" (which set out minimum employment conditions and pay rates for different industries and occupations). The existence of minimum wages should work to compress wage differentials between permanent and temporary workers, particularly at the bottom of the distribution. However, this assumption should be qualified since the different types of temporary work receive different treatment within Australia's system of wages and employment regulation.

A longstanding feature of awards has been the explicit recognition of casual employment as a distinct category of employment. Casual employees usually do not have any legal entitlement to paid leave (notably annual leave and sick leave), paid public holidays, minimum periods of notice of termination, or severance pay. To compensate for the absence of these entitlements, however, casual employees are usually entitled to a pay loading. Prior to July 2010, the level of the pay loading varied depending on rates specified either in an enterprise agreement or the award applicable to a worker's employer. During the late 1990 s and early 2000 s this loading was usually $20 \%$ of the wage of a comparable non-casual worker (Watson 2005; Wooden 2001a). In the wake of the restructuring of the awards system in 2010, new legislation required that all casual loadings in awards be gradually increased to at least $25 \%$, taking full effect in July 2014. Furthermore, while the casual loading is only obligatory for workers on the national minimum wage or minimum award rates, the provision of a casual loading is also common practice in enterprise agreements. 
The provision for a pay loading suggests that Australian casual employees should be likely to receive compensating wage differentials, especially in the lower half of the distribution where minimum award wages and the national minimum wage take effect. However, there are several reasons why we might still not observe a pay premium for casual workers. First, casual employees are more likely to be paid at award rates, whereas permanent employees are more likely to be covered by enterprise and individual agreements, which typically involve pay at above award rates. ${ }^{1}$ In part, this reflects the tendency for casual employment to be concentrated in lower skilled, and hence lower paid, jobs. But it may also be a consequence of the greater use of casual employment by small firms (see Table 3), where enterprise bargaining is relatively uncommon and which tend to rely on wage rates specified in awards. We also suspect that small firms are less likely to be compliant with award regulation.

Second, the bargaining power of casual workers is typically low: Not only can they be dismissed anytime at little cost to the employer, but they are also concentrated in occupations and industries with relatively high unemployment. Many low-skilled workers are thus confronted by the choice between a casual job or unemployment. Unemployment benefits in Australia, however, are relatively low ${ }^{2}$ and means-tested, ereating incentives for unemployed workers to accept the first job available. Casual employees are also far less likely to be members of, and thus receive the protections afforded by, trade unions (see Table 3).

Third, it is expected that casual workers will be more likely to prefer flexible work arrangements to high wages given, in theory, such workers are not bound to a fixed number of hours and can refuse shifts that do not suit them. The pay loading prescribed in wage legislation might be considerably offset by these factors.

In contrast to casual employment, fixed-term contracts generally come with the same entitlements as permanent contracts (e.g., with respect to paid leave and paid holidays), and there is no regulatory requirement for a pay loading. Furthermore, the job security of fixed-term contract workers is arguably greater than that of casual employees: The former have an expectation that employment will last until at least the end of their current contract, while, as repeatedly mentioned, the latter can be dismissed at any time. The need for compensating wage differentials is thus less for fixed-term contract employees than for casual employees.

Finally, we have temporary agency workers. This group is exceptional in that they can be hired on a permanent, fixed-term or casual basis. HILDA Survey data for 2015 show that $49 \%$ of temporary agency workers were employed on casual contracts, $31 \%$ on fixed-term contracts and $19 \%$ on permanent contracts. A large group of agency workers will therefore be entitled to the casual loading.

\section{Data and method}

\section{Data and sample}

We use data from fifteen waves of the HILDA Survey, a longitudinal study that commenced in 2001 and follows members of a nationally representative sample of Australian households (see Watson and Wooden 2012). A total of 11,693 households were identified as in-scope at wave 1, with interviews completed with members of 7682 of these households (providing an initial responding sample of 13,969 persons). ${ }^{3}$ Interviews are conducted with all adult (persons aged 15 years or older) members of the original sample, as well as any other adults who, in later waves, are residing with an original sample member. Annual re-interview rates are high, rising from $87 \%$ in wave 2 to $96 \%$ by wave 9 .

Among other topics, the HILDA Survey provides comprehensive information on individuals' employment situations. The sample used here is restricted to employees aged between 21 and 64 
years. ${ }^{4}$ Observations where the respondent did not report whether they were employed on a permanent, fixed-term or casual contract, where hourly wages could not be calculated due to missing information on usual weekly working hours, or where the hourly wage seemed extreme (below A $\$ 5$ and above A \$200), were also excluded. These exclusions resulted in the loss of just 253, 185 and 1320 observations respectively. The final working sample comprised 8689 men and 8876 women, contributing 49,584 and 49,740 observations respectively.

\section{Method}

Most studies of the relationship between temporary employment and wages at different points in the wage distribution have used conditional quantile regression methods, as developed by Koenker and Bassett (1978). In this approach, the quantiles of the distribution are defined by the covariates, meaning the coefficients designate the effect on the conditional distribution rather than the unconditional distribution of the outcome variable. For example, if we investigate wage outcomes for casual compared to permanent workers at the $10^{\text {th }}$ decile of the wage distribution and additionally control for educational level, the resulting coefficient for casual work measures the average wage differential between casual and permanent workers at the $10^{\text {th }}$ decile of the separate wage distributions for each educational level. As workers at the $10^{\text {th }}$ decile of the wage distribution for postgraduates can be expected to have a much higher wage than workers at the $10^{\text {th }}$ decile of the distribution for workers who did not finish high school, the resulting averaged coefficient is difficult to interpret. Furthermore, the inclusion of additional covariates alters the interpretation of the quantiles, impeding the comparison of coefficients across models with different covariates.

In contrast, our analysis makes use of unconditional quantile regression (UQR), as developed by Firpo et al. (2009). Within this framework, the quantiles are defined pre-regression and therefore do not vary with the additional covariates included in the model. This method involves regressing the Recentered Influence Function (RIF) of the unconditional quantile of the dependent variable on the explanatory variables. The RIF is calculated as follows:

$$
\left(Y ; q_{\tau}, F_{y}\right)=q_{\tau}+\left[\left(\tau-\mathbb{1}\left\{Y \leq q_{\tau}\right\}\right) / f_{y}\left(q_{\tau}\right)\right]
$$

where $Y$ is the outcome variable (the hourly wage), $\tau$ designates the specific quantile, $q_{\tau}$ is the value of the outcome variable at this quantile, $F_{y}$ is the unconditional (marginal) distribution function of $Y$, $f_{y}\left(q_{\tau}\right)$ is the density at the point $q_{\tau}$ (as estimated by kernel methods), and $\mathbb{1}\left\{Y \leq q_{\tau}\right\}$ is a dummy variable indicating whether the outcome variable is below $q_{\tau}$. The RIF is then used as the dependent variable in a least squares regression. The RIFs and the subsequent regressions are calculated separately for men and women, and standard errors are bootstrapped (50 replications) and clustered on individuals.

Unlike previous studies, we also incorporate individual fixed effects into the UQR using the Stata command xtrifreg, an extension to the Firpo et al. estimator recently developed by Borgen (2016). Use of xtrifreg overcomes the problems of computational feasibility and difficulty calculating standard errors that previous approaches to the incorporation of fixed effects into UQR have confronted.

The main advantage of fixed-effects regression is the removal of the effect of (time-constant) unobserved person-specific traits. The downside of this approach is that wages of workers who are only observed onee or who never change employment type over the observation period are not used in the estimation. However, due to the long-run nature of the panel, the large majority of our working sample are observed in employment at least twice - while $21.8 \%$ of workers (3808) in our sample are observed in employment only once, these cases only represent $3.8 \%$ of total observations. Further, among the group of workers who are observed repeatedly, most (7526) transition between employment types (compared to 6231 persons who do not transition). 
Additional information on the nature of the sample, and in particular how the characteristics of those that change employment type differ from those that do not, is reported in Tables 1 and 2. Table 1 shows that temporary workers are more likely to change employment type than permanent workers, with $57 \%$ of fixed-term contract workers, $35 \%$ of casual workers and $64 \%$ of temporary agency workers leaying their employment type each year, compared to $10 \%$ of permanent workers. Temporary workers, especially fixed-term contract workers, are also more likely to transition into permanent employment than vice versa, suggesting that temporary employment is often a stepping stone to permanent employment. When looking at the characteristics of those workers who change employment type and those who do not (see Table 2), we find that changers receive lower hourly wages on average and are slightly younger than workers who do not change employment types. There are, however, no major differences in terms of educational qualifications or other demographic characteristics.

For comparative purposes, we also report results from pooled cross-sectional UQRs. Comparing these results with those from our preferred fixed-effects UQRs enables assessment of the role unobserved heterogeneity plays in the temporary-permanent wage gap. We also present results from regressions where wages are measured at the mean. The difference between these results and the results from quantile regression highlight the extent to which conventional regression methods conceal variation in the wage gap across the distribution.

Finally, it should be noted that our approach still does not enable causal inferences to be made with any confidence. Despite accounting for fixed effects, our results may still be affected by selection on (time-varying) unobservables.

\section{Dependent variable}

The dependent variable is the natural logarithm of the hourly wage deflated by the Australian Wage Price Index (using September values with 2008/09 as base year) produced by the Australian Bureau of Statistics. Hourly wages are derived by dividing usual gross weekly wages and salary from the main job by the number of hours worked in that job during a usual week (where working hours include both paid and unpaid overtime).

\section{Employment type}

We distinguish between permanent employment, fixed-term contracts, casual employment and temporary agency work. The first three categories are mutually exclusive. Temporary agency workers, however, could be employed on either a permanent, fixed-term or casual basis. We thus create a fourth category, with all employees who report being employed through a labour-hire firm or temporary employment agency, regardless of their contract type, classified as temporary agency workers.

\section{Control variables}

Our preferred specification (specification 1) includes controls for a range of socio-demographic and work-related characteristics. We include age (in quadratic form), six dummies for the highest educational level, and a separate dummy for full-time students. The household context is considered by including a dummy for individuals living with a partner and a second dummy for those living with their own children below the age of 15 . An indicator for the presence of a long-term health condition that impacts on work is also included. We account for regional differences in wage levels in two ways: first, by the inclusion of variables identifying residence in a major city, an inner-regional area, or a more remote area; and second, through the inclusion of indicators for the eight different 
Australian states and territories. We also control for time effects through the inclusion of year dummies. In the pooled cross-sectional models, we additionally control for indigenous origin and region of birth. Regarding employment-related variables, we include controls for length of tenure with the current employer (specified as a quadratic), whether employed in the public sector, whether has supervisory responsibilities, whether works a schedule other than a regular day schedule, whether had experienced any unemployment in the past year, and membership of a trade union or employee association

In another specification (specification 2), we additionally include controls for employment characteristics that are closely correlated with employment type. These are: working hours, represented by dummies for part-time work (less than 35 hours per week) and long hours (46 hours or more); firm size, represented by dummy variables identifying firms with fewer than 20, 20 to 99, and 500 or more employees; occupation, with seven dummies included to identify the eight major groups within the Australian and New Zealand Standard Classification of Occupations ${ }^{5}$; and industry, with 18 dummies included to identify the 19 major divisions within the Australian and New Zealand Standard Industrial Classification.

Summary statistics for all variables, differentiated by employment type, are provided in Table 3 .

\section{Results}

Table 4 summarises the mean hourly wages for men and women by employment type within the sample. The results reflect the well-known gender wage gap, with women on average receiving A $\$ 25$ per hour and men $A \$ 29$. Women also earn less than men in every single employment type, although the difference is comparatively small among casual employees. When comparing wages across employment types, for both men and women, temporary agency and fixed-term contract workers receive the highest hourly wages, followed by permanent employees, but the differences between these groups are relatively small and mostly insignificant. Casual employees, in contrast, earn considerably lower wages on average than workers in the other three categories.

To investigate to what extent the raw wage differential can be explained by observed and unobserved-worker characteristics, we turn to multivariate regression models. Table 5 reports the estimates of most interest from four types of models: (i) conventional pooled ordinary least squares (OLS) regression (where the hourly wage is measured at its mean); (ii) unconditional quantile regression (where estimates are reported for seven selected percentiles); (iii) conventional fixed effects regression (where the wage is again measured at its mean); and (iv) unconditional fixed-effects quantile regression. All models are unweighted and estimated separately for men (Panel A) and women (Panel B) using specification 1.

\section{Wage gaps at the mean}

Starting with the conventional OLS model for men, we see that, relative to permanent employment, fixed-term contracts and temporary agency work are both associated with a significant wage premium at the mean, with this premium being much larger for agency workers (14\%) than for fixed-term contract workers $(4 \%)$. Casual work, in contrast, is associated with a small, but significant, wage penalty for men. Once we account for individual fixed effects (reported in the bottom half of Panel A of Table 5), the wage premium for both fixed-term and temporary agency workers becomes smaller. Indeed, the premium for fixed-term workers disappears almost entirely. In contrast, the wage penalty for men in casual jobs becomes a modest $5 \%$ premium. These findings are consistent with the expectation that part of the observed raw wage differentials across employment types can be 
explained by differences in unobserved characteristics of workers, such as ability, motivation or personality traits. Less obvious, our results suggest that the importance of these unobservable characteristics varies markedly with employment type. Fixed-term contract and temporary agency workers appear to have unobservable traits that are associated with relatively high productivity, whereas casual employees tend to have traits associated with low productivity.

The results for yomen (reported in Panel B) are similar, but with the notable exception that the wages of fixed-term contract workers do not differ significantly from permanent workers. For casual employment, as was found for men, a small wage penalty is suggested by the OLS model, which becomes a modest premium (5\%) once individual fixed effects are included. And as for men, both the OLS and fixed-effects models suggest that, at the mean of the wage distribution, there is a premium for temporary agency work among women in the order of 7 to $8 \%$.

\section{Wage differentials across the distribution}

Turning to the results from the quantile regressions, we see that the mean regressions hide large variations in the temporary-permanent wage gap across the wage distribution. Comparing the results from the $5^{\text {th }}$ to the $95^{\text {th }}$ percentile, we find a similar pattern for all three temporary employment types and for both genders: There is a wage penalty for temporary employees at the bottom of the wage distribution, which gradually turns into a wage premium towards the top of the distribution. The exception to this pattern is female fixed-term contract workers, who experience a small wage penalty at the $75^{\text {th }}$ percentile. Comparing the results for the conventional UQR and the fixed-effects UQR, the overall pattern persists but becomes less pronounced when controlling for unobserved heterogeneity. Notably, the wage penalty at the bottom of the distribution decreases, particularly for casual employees. The wage premium at the top also decreases, at least among temporary agency workers and men on fixed-term contracts. In contrast, for casual employees of both genders, the wage premium at the top increases upon accounting for fixed effects.

We now consider the results for the fixed-effects UQR in more detail with a view to describing how these estimated wage differentials evolve across the whole wage distribution, rather than just at the selected quantiles presented in Table 5. Figures 1 and 2 present results for separate estimations of the wage effects at all 99 percentiles for men and women respectively. ${ }^{6}$ Again, the estimation is based on specification 1.

Focussing first on the results for men, summarised in Figure 1, we can see that fixed-term contract workers have hourly wage outcomes that at almost all points in the wage distribution are little different from comparable permanent employees. There is only a small significant wage penalty at the very bottom of the distribution (a maximum of $5 \%$ at the $3^{\text {rd }}$ percentile) and a small significant wage premium at the top (up to $7 \%$ at the $97^{\text {th }}$ percentile). Very different are casual employees. Male casual employees at the bottom of the wage distribution receive a sizeable wage penalty $\left(16 \%\right.$ at the $1^{\text {st }}$ percentile), but at most points in the distribution casual employees receive a modest wage premium. Further, this premium increases with a worker's position in the wage distribution, reaching $17 \%$ at the $99^{\text {th }}$ percentile. Nevertheless, at no point is this estimated premium as large as $20 \%$, the loading that most employers were required to pay casual employees. Different again are temporary agency workers. With the exception of a statistically insignificant wage penalty at the very bottom, they receive a wage premium at all points in the wage distribution, with that premium reaching very high levels at the top of the distribution: $47 \%$ at the $95^{\text {th }}$ percentile and $97 \%$ at the $99^{\text {th }}$ percentile. 
The patterns of wage differentials for women, presented in Figure 2, are similar to those found for men. The wages of female fixed-term contract workers also do not differ significantly from those of permanent workers throughout most of the wage distribution. Also, the casual-permanent wage differential moves from a pronounced penalty at the bottom of the distribution to a sizeable premium at the top. Indeed, the slope in this relationship between the estimated wage differential and the wage percentile is more pronounced for women than for men: There is both a larger wage penalty at the bottom (up to $19 \%$ at the $1^{\text {st }}$ percentile) and a larger wage premium at the top of the distribution. Nevertheless, most female casual employees still do not receive hourly wage premiums in excess of the standard $20 \%$ award requirement. Only those in the top 5\% of the wage distribution receive a premium of this magnitude ( $20 \%$ at the $95^{\text {th }}$ percentile up to $43 \%$ at the $99^{\text {th }}$ percentile). Female temporary agency workers also experience a wage penalty at the bottom of the distribution, but this is both less pronounced than for female casual employees and statistically insignificant. And like male agency workers they also attract large premiums at the top (up to $102 \%$ at the $99^{\text {th }}$ percentile).

Overall, the results point to the presence of wage penalties for casual and temporary agency work at the bottom of the distribution but small premiums throughout most parts of the distribution, increasing to comparatively high levels near the very top. Gauging the extent to which workers are advantaged or disadvantaged by their employment contract type, however, requires taking into account the chances of temporary workers being found at different points of the wage distribution. Such information is presented in Figures 3 and 4.

These figures show that among both genders, casual employees are overrepresented in the bottom half of the wage distribution and under-represented at the top. The number of casual workers benefiting from the wage premium at the top of the distribution is therefore rather small compared to the number of workers experiencing the penalty at the bottom. The pattern is slightly different for temporary agency workers: They also have an increased likelihood to be found at the bottom of the distribution but are also considerably overrepresented at the top. The wage distribution of fixed-term contract workers, in contrast, is similar to that of permanent workers.

\section{Robustness checks}

We re-analysed the data with several modified models to test the robustness of our results. The key estimates from these alternative specifications are presented in Online Appendix Tables A3 and A4. ${ }^{7}$

\section{(a) Variable modifications}

We included additional covariates (indicators for working hours, firm size, occupation, and industry) that we suspected were closely linked with temporary employment (specification 2). Among men, the wage premium for temporary agency workers shrinks only slightly and does so evenly throughout the distribution. In contrast, the premium for casual workers disappears almost entirely, with the reduction being largest at the top of the distribution. Overall, male casual employees are left with only a modest wage premium of around 2 to $3 \%$ throughout the distribution. Further examination reveals that the reduction of the casual premium is entirely driven by the control for working hours, with hourly wages declining with the number of hours worked. This finding suggests that casual employees (and especially men) receive higher wages not because they are on a casual contract but because they tend to work fewer hours than permanent workers, and for many of the latter, pay does not rise with hours worked. For fixed-term contract work, the analysis confirms the results of specification 1 there is little difference in the hourly wages of fixed-term and permanent workers. For women, the overall trajectories remain the same, yet the premiums for agency workers as well as for casual employees in the top third of the distribution are attenuated. 
We also: (i) modified specification 2 using a more disaggregated list of occupations; (ii) reestimated specification 1 models after omitting job tenure, given potential collinearity with employment type; and (iii) checked if results were sensitive to the use of the hourly wage in all jobs rather than the main job as outcome variable, given the incidence of multiple job holding may vary by employment type. In each of these cases, the key parameters were little affected.

(b) Sample modifications

We also re-estimated the specification 1 models with modified samples. First, we created a balanced panel and compared the results from separate analyses with and without longitudinal weights to account for potential biases arising from attrition and non-response. The general pattern of results is unchanged from the unweighted analyses using the full sample and, more importantly, the differences between the weighted and unweighted estimations are minor. Second, we removed older workers $(>45$ years) from the sample given that workers who change jobs are concentrated among the young. Again, the results did not change noticeably.

(c) Group comparisons

Finally, we conducted heterogeneity analyses by comparing the effects for different groups of workers using specifieation 1 .

First, the considerable wage premium for high-paid temporary agency workers gave reason to have a closer look at wage differences within the group of agency workers. We therefore re-estimated the models with the group of agency workers split into three categories by type of contract (permanent, fixed-term or castal), and with the reference category being direct-hire permanent workers. For both genders, the wage premium at the top of the distribution is largest for agency workers employed on fixed-term contracts. Casual agency workers receive a smaller premium than fixed-term agency workers, but it is larger than the premium for direct-hire casual workers (especially among men). High-paid male agency workers on permanent contracts receive a similar premium to casual agency workers. In contrast, female agency workers on permanent contracts receive no premium at all.

Second, we tested the impact of the gradual increase in the legally prescribed casual loading since 2010, by comparing results from two separate models for the periods 2001 to 2009 and 2010 to 2015 . The results show that for women, the casual wage penalty at the bottom of the distribution was mainly confined to the earlier period. The change in legislation thus appears to be associated with an improvement in the wages of some of the most disadvantaged workers.

Third, given temporary forms of employment are relatively concentrated in certain types of jobs and industries, and given wage outcomes will vary across occupations and industries, we examined whether estimates differed across sectors. Sample size considerations dictated that our comparisons would be very crude; specifically, we compared results from separate models for high-skilled and low-skilled workers (defined by major occupations), as well as for workers in the primary / secondary sector and those in the tertiary sector. As expected, both occupation and industry matter. The wage premium for casual and temporary agency workers is largely confined to tertiary (i.e., service) industries. Indeed, among male workers in primary and secondary industries we find no evidence of a wage premium for casual work anywhere in the wage distribution. Wage premiums for casual work are more pronouneed among the highly skilled, and for men in this group they vary little across the wage distribution, averaging around $10 \%$. Nevertheless, when we focus on the sectors where casual workers are most concentrated (low-skilled occupations and tertiary industries) the patterns in the estimated wage premiums vary little from the estimates obtained for the entire sample. 


\section{Discussion and Conclusion}

Using a large nationally representative household panel dataset for Australia, this paper provides new evidence on the wage gap between permanent and temporary workers, and especially the size of the wage gap at different points in the wage distribution. The results emphasise the heterogeneous wage outcomes of different types of temporary employment. For casual employees, the analysis revealed a wage penalty at the bottom of the wage distribution, but a wage premium in most other parts of the distribution. Yet, with the exception of (the few) female casual employees at the top of the wage distribution, nowhere is the wage premium near the $20 \%$ specified in most industrial awards and agreements during the period covered by our data. The wage premium for male casual employees even disappears almost entirely when a more extensive set of control variables is considered. The absence of a wage premium, despite award provisions for a casual loading, does not, however, necessarily imply widespread employer non-compliance with wage legislation. Awards only specify minimum wages, and non-casual employees are far more likely to be paid at rates above the relevant minimum award wage. Nevertheless, the marked penalty at the bottom of the wage distribution is suggestive of considerable non-compliance on the part of employers of low-wage casual labour.

Temporary agency workers appear to be in a better situation than casual workers. Notably, agency workers at the bottom of the distribution do not receive a wage penalty, and the wage premium at the top is more pronounced than that for casual employees. Among the high-paid agency workers, we therefore see evidence for compensating wage differentials for the insecurity and flexibility associated with agency work. This is particularly true for agency workers employed on fixed-term contracts, who receive by far the largest wage premium. We also found that the wage premium for agency workers employed on a casual basis is higher than that for other casual workers, suggesting that it might be easier to enforee the pay loading with the help of a temporary employment agency.

In contrast, fixed-term contract workers of both genders receive very similar wages to permanent workers throughout the distribution. This result differs from European studies, which have found significant wage penalties for fixed-term workers at all points in the distribution. We suspect that this difference reflects the specific configuration of temporary work in Australia, with casual work instead of fixed-term contracts being the major vehicle for meeting fluctuations in demand.

An implication of our results is that a focus on the mean wage gap disguises important inequalities between permanent and temporary workers and within the group of temporary workers. For example, high-paid temporary agency workers succeed in turning their flexibility into an asset and achieve a wage premium on top of their higher wage. This particularly applies to fixed-term contract agency workers, who additionally are entitled to similar working conditions (including leave provisions) as permanent workers. In contrast, low-paid casual workers are at a multiple disadvantage. These workers, who are not entitled to paid leave and who are more likely to experience fluctuating earnings and involuntary job loss, receive hourly wages that are low relative to not only other workers in the distribution but to otherwise similar permanent workers.

Given that low-paid casual employment is highly prevalent in Australia, this study suggests that this form of employment might be one factor driving overall wage inequality in Australia. That said, the relationship between casual employment and aggregate wage inequality is not straightforward. For example, despite the high casual employment share, wage inequality is not noticeably higher in Australia than in many other OECD countries (International Labour Organization 2017: 22).

Our findings are also of large significance given the recent decision by the Fair Work Commission, Australia's national workplace relations tribunal, to introduce a clause in awards that will allow casual employees who have, for one year, worked a regular pattern of hours with an employer, to request 
conversion to permanent employment. How many casual employees will seek conversion will depend on the perceived benefits of doing so. The $25 \%$ pay loading is widely regarded as a powerful

disincentive to conversion. The results presented here, however, suggest that many casual employees, especialty those working in low-skilled occupations, may be better off converting.

In terms of future policy interventions, the results point to the potential impotence of minimum wage regulation. While we cannot quantify the extent of the problem, the findings suggest that many casual employees are paid at rates below what is legally required. Addressing this issue will require more resources devoted to enforcement, which will be expensive, especially given the concentration of casual labour in small business.

Finally, despite the methodological advances employed in this study, it is not without limitations. Our study cannot account for firm-specific effects that affect the temporary-permanent wage gap. We might, therefore, underestimate the temporary wage premium if firms that pay lower wages in general are at the same time more likely to employ temporary workers. Unveiling this relationship would, however, require the availability of linked employer-employee data. Further, given the absence of a suitable instrument, we are unable to account for the time-varying part of unobserved heterogeneity that might affeet both selection into temporary employment and workers' wages. We thus cannot rule out the possibility that our results are affected by self-selection on unobservables.

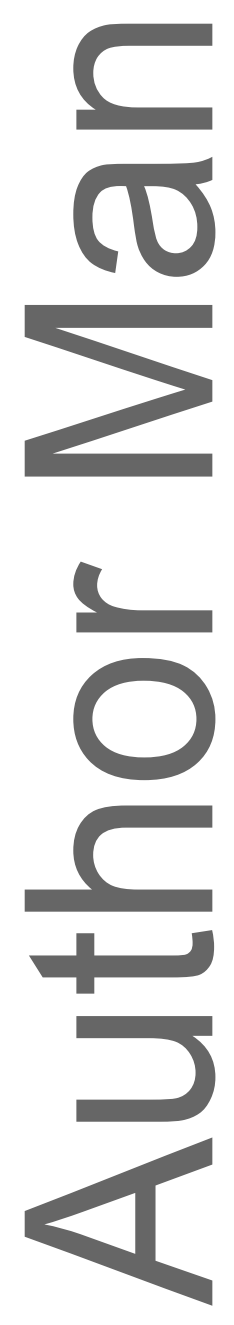




\section{Notes}

1 In 2016 almost $45 \%$ of casual (non-managerial) employees were paid exactly the award rate, compared to $18 \%$ of permanent (non-managerial) employees (ABS 2017, Data Cube 5, Table 2). 2 As OECD data (https://stats.oecd.org/) show, Australian net replacement rates after becoming unemployed are among the lowest in the OECD.

3 A population refreshment sample was introduced in 2011, which added a further 2153 responding households.

4 Exclusion of the self-employed might be problematic if some of these workers are substitutes for temporary employees. This might, for example, apply to self-employed 'gig workers'. Consequences for our analysis, however, are likely to be small. The most detailed Australian study of the size of the gig economy has estimated that less than half of one percent of Australian adults do any work found or performed on an online platform (Minifie and Wiltshire 2016), and in most cases this work involves very few hours each week.

5 For information on the typical occupations held by workers in different employment types at different points of the wage distribution see Online Appendix Tables A1 and A2.

6 The confidence intervals relating to these estimations are presented in Online Appendix Figure A1. 7 Additionally, we have investigated in more detail the role played by union membership (given union influence over enterprise bargaining outcomes) and firm size (given the likelihood of adopting formal bargaining processes and complying with award-based regulation will vary with firm size). More specifically, we estimated two additional sets of models (using specification 2) that included interaction terms for employment type and union membership / firm size. The results (which are available on request) suggest that the effect of these factors on the temporary-permanent wage gap is complex and gender-specific. 


\section{References}

Atkinson, J. (1984). 'Manpower strategies for flexible organisations'. Personnel Management, 16(8): $28-31$.

Australiann Bureau of Statistics (ABS) (2017). Employee Earnings and Hours, Australia, May 2016 (ABS cat. no. 6306.0). Canberra: Australian Bureau of Statistics.

Bentolila, S. and Dolado, J. J. (1994). 'Labour flexibility and wages: lessons from Spain'. Economic Policy, 9(18): 53-99.

Boockmann, B. and Hagen T. (2005). 'Die Bedeutung befristeter Arbeitsverhältnisse für die Zugänge und den Verbleib in Beschäftigung'. In M. Kronauer and G. Linne (eds.), Flexicurity: Die Suche nach der Sicherheit in der Flexibilität. Berlin: Edition Sigma, pp. 149-68.

Booth, A. L., Francesconi, M. and Frank, J. (2002a). 'Labour as a buffer: do temporary workers suffer?' IZA Discussion Paper 673. Bonn: Institute for the Study of Labor.

Booth, A. L. Francesconi, M. and Frank, J. (2002b). 'Temporary jobs: stepping stones or dead ends?' Economic Journal, 112(480): F189-F213.

Borgen, N. (2016). 'Fixed effects in unconditional quantile regression'. The Stata Journal, 16(2): 403-15.

Bosio, G. (2009). Temporary employment and wage gap with permanent jobs: evidence from quantile regression'. MPRA Paper 16055. Munich: Munich Personal RePEc Archive.

Bosio, G. (2014). 'The implications of temporary jobs on the distribution of wages in Italy: an unconditional IVQTE approach'. Labour, 28(1): 64-86.

Cai, L. and Liu, A.Y. C. (2008). 'Union wage effects in Australia: is there variation along the distribution?' Economic Record, 84(267): 496-510.

Campbell, I. (1996). 'Casual employment, labour regulation and Australian trade unions'. Journal of Industrial Relations, 38(4): 571-99.

Comi, S. and Grasseni, M. (2012). 'Are temporary workers discriminated against? evidence from Europe'. The Manchester School, 80(1): 28-50.

Daw, J. and Hardie, J. H. (2012). 'Compensating differentials, labor market segmentation, and wage inequality'. Social Science Research, 41(5): 1179-97.

Draca, M. and Green, C. (2004). 'The incidence and intensity of employer funded training: Australian evidence on the impact of flexible work'. Scottish Journal of Political Economy, 51(5): 609-25.

Faccini, R. (2014). 'Reassessing labour market reforms: temporary contracts as a screening device'. Economic Journal, 124(575): 167-200.

Firpo, S., Fortin, N. M. and Lemieux T. (2009). 'Unconditional quantile regressions'. Econometrica, 77(3): 953-73.

Gash, V. and McGinnity, F. (2006). 'Fixed-term contracts - the new European inequality? comparing men and-women in West Germany and France'. Socio-Economic Review, 5(3): 467-96.

Giesecke, J. and Groß, M. (2003). 'Temporary employment: chance or risk?' European Sociological Review, 19(2): 161-77.

Giesecke, J. and Groß, M. (2004). 'External labour market flexibility and social inequality'. European Societies, 6(3): 347-82.

Green, C., Kler, P. and G. Leeves, G. (2010). 'Flexible contract workers in inferior jobs: reappraising the evidence'. British Journal of Industrial Relations, 48(3): 605-29.

Green, C. P. and Leeves, G. D. (2013). 'Job security, financial security and worker well-being: new evidence on the effects of flexible employment'. Scottish Journal of Political Economy, 60(2): $121-38$. 
Gumbrell-McCormick, R. (2011). 'European trade unions and 'atypical' workers'. Industrial Relations Journal, 42(3): 293-310.

International Labour Office (2004). 'On-call work and "zero hours” contracts.' ILO Information Sheet No. WT-15. Geneva: International Labour Organization.

International Labour Organization (ILO) (2017). Global Wage Report 2016/17: Wage Inequality in the Workplace. Geneva: ILO.

Kalleberg, A.L., Reskin, B. and Hudson, K. (2000). 'Bad jobs in America: standard and nonstandard employment relations and job quality in the United States'. American Sociological Review, 65(2): 256-78.

Koenker, R. and G. Bassett. (1978). 'Regression quantiles'. Econometrica, 46(1): 33-50.

Lindbeck, A. and Shower, D. J. (2001). 'Insiders versus outsiders'. Journal of Economic Perspectives, 15(1): 165-88.

Mertens, A.,Gash, V. and McGinnity, F. (2007). 'The cost of flexibility at the margin: comparing the wage penalty for fixed-term contracts in Germany and Spain using quantile regression'. Labour, 21(4-5): 637-66.

Mertens, A. and McGinnity, F. (2005). 'A "two-tier" labour market for fixed-term jobs? evaluating evidence from West Germany using quantile regression'. Schmollers Jahrbuch, 125(1): 75-85.

Minifie, J. and Wiltshire, T. (2016). Peer-to-Peer Pressure: Policy for the Sharing Economy (Grattan Institute Report no. 2016-7). Melbourne: Grattan Institute.

Nienhüser, W. and Matiaske, W. (2006). 'Effects of the "principle of non-discrimination" on temporary agency work: compensation and working conditions of temporary agency workers in 15 European countries'. Industrial Relations Journal, 37(1): 64-77.

OECD (2015). In It Together: Why Less Inequality Benefits All. Paris: OECD Publishing.

Rosen, S. (1986). 'The theory of equalizing differences'. In O. Ashenfelter and R. Layard (eds.), Handbook of Labor Economics: Volume 1. Amsterdam: North Holland, pp. 641-92.

Santangelo, G. (2011). 'Do temporary contracts cause wage discrimination? a quantile treatment effect analysis for Europe'. Paper presented at the XXVI National Conference of Labour Economics, Milan.

Schmitt, J. (2008). The Union Wage Advantage for Low Wage Workers. Washington DC: Center for Economic and Policy Research.

Sørensen, A. B. (1983). 'Processes of allocation to open and closed positions in social structure'. Zeitschrift für Soziologie, 12(3): 203-24.

Watson, I. (2005). Contented workers in inferior jobs? re-assessing casual employment in Australia'. Journal of Industrial Relations, 47(4): 371-92.

Watson, N. and Wooden, M. (2012). 'The HILDA Survey: a case study in the design and development of a successful household panel study'. Longitudinal and Life Course Studies, 3(3): 369-81

Wooden, M. (2001a). 'How temporary are Australia's casual jobs?' Work, Employment \& Society. 15(4): 875-83.

Wooden, M. (2001b). 'Union wage effects in the presence of enterprise bargaining'. Economic Record, 77(236). 1-18. 


\section{TABLE 1}

\begin{tabular}{|c|c|c|c|c|c|}
\hline \multirow{2}{*}{$\begin{array}{l}\text { Employment type } \\
\text { at year } t\end{array}$} & \multicolumn{5}{|c|}{ Employment type at year $t+1$} \\
\hline & Permanent & Fixed-term & Casual & $\begin{array}{c}\text { Temporary } \\
\text { agency }\end{array}$ & Total \\
\hline Permanent & $\begin{array}{l}50,606 \\
(90.3)\end{array}$ & $\begin{array}{c}2,961 \\
(5.3)\end{array}$ & $\begin{array}{l}1,878 \\
(3.4)\end{array}$ & $\begin{array}{c}584 \\
(1.0)\end{array}$ & $\begin{array}{l}56,029 \\
(100.0)\end{array}$ \\
\hline Fixed-term & $\begin{array}{l}3,441 \\
(49.6)\end{array}$ & $\begin{array}{l}2,995 \\
(43.1)\end{array}$ & $\begin{array}{c}390 \\
(5.6)\end{array}$ & $\begin{array}{c}119 \\
(1.7)\end{array}$ & $\begin{array}{c}6,945 \\
(100.0)\end{array}$ \\
\hline Casual & $\begin{array}{l}2,688 \\
(25.8)\end{array}$ & $\begin{array}{l}720 \\
(6.9)\end{array}$ & $\begin{array}{l}6,711 \\
(64.5)\end{array}$ & $\begin{array}{c}282 \\
(2.7)\end{array}$ & $\begin{array}{l}10,401 \\
(100.0)\end{array}$ \\
\hline Temporary ag & $\begin{array}{c}737 \\
(40.8)\end{array}$ & $\begin{array}{c}152 \\
(8.4)\end{array}$ & $\begin{array}{c}271 \\
(15.0)\end{array}$ & $\begin{array}{c}645 \\
(35.7)\end{array}$ & $\begin{array}{c}1,805 \\
(100.0)\end{array}$ \\
\hline Total & $\begin{array}{c}57,472 \\
(76.5)\end{array}$ & $\begin{array}{c}6,828 \\
(9.1)\end{array}$ & $\begin{array}{l}9,250 \\
(12.3)\end{array}$ & $\begin{array}{l}1,630 \\
(2.2)\end{array}$ & $\begin{array}{l}75,180 \\
(100.0)\end{array}$ \\
\hline
\end{tabular}

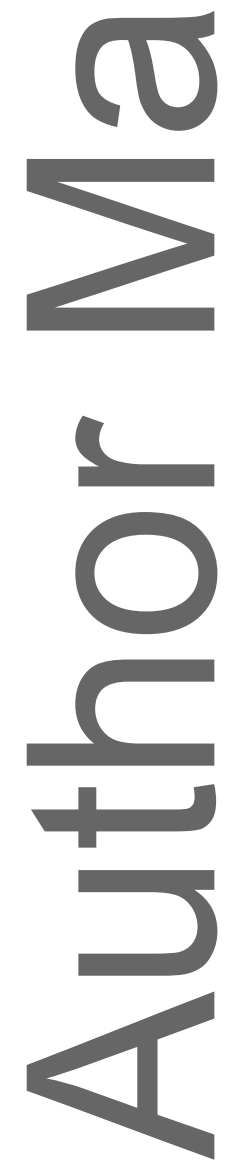




\section{TABLE 2}

Characteristics of sample members by times observed in employment and whether employment type changed (means based on total person-year observations)

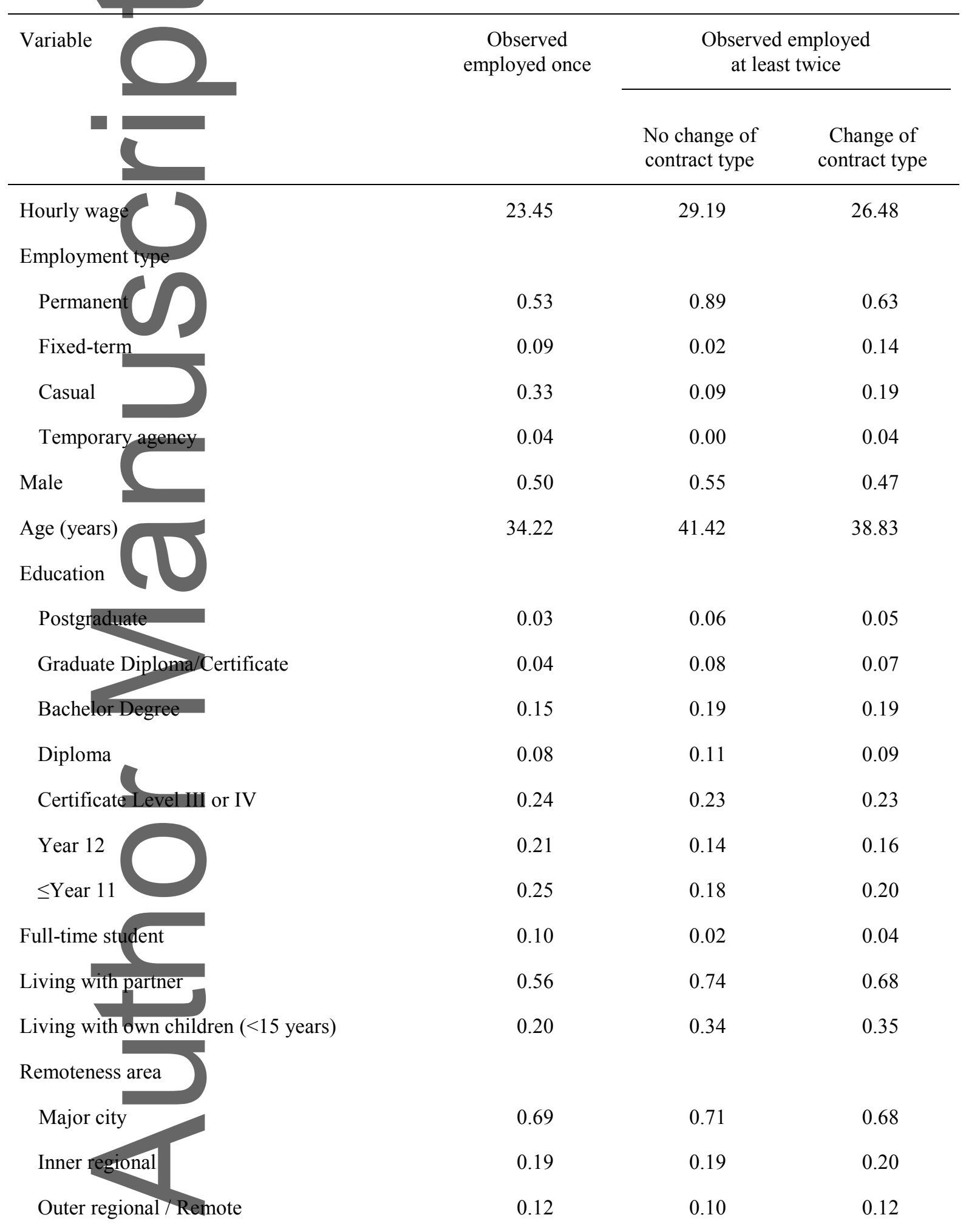

State 


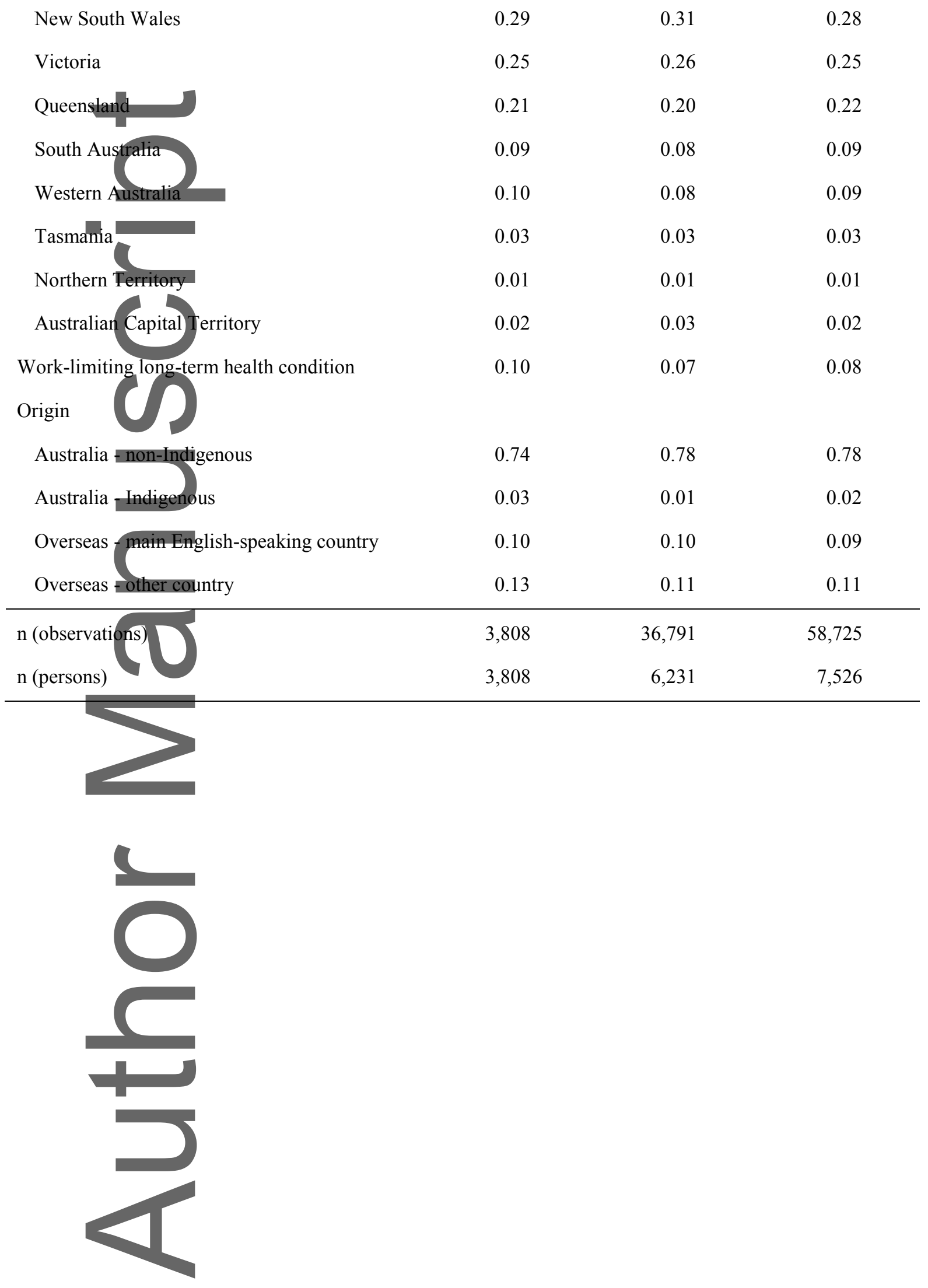

This article is protected by copyright. All rights reserved. 
TABLE 3

Summary Statistics (Means)

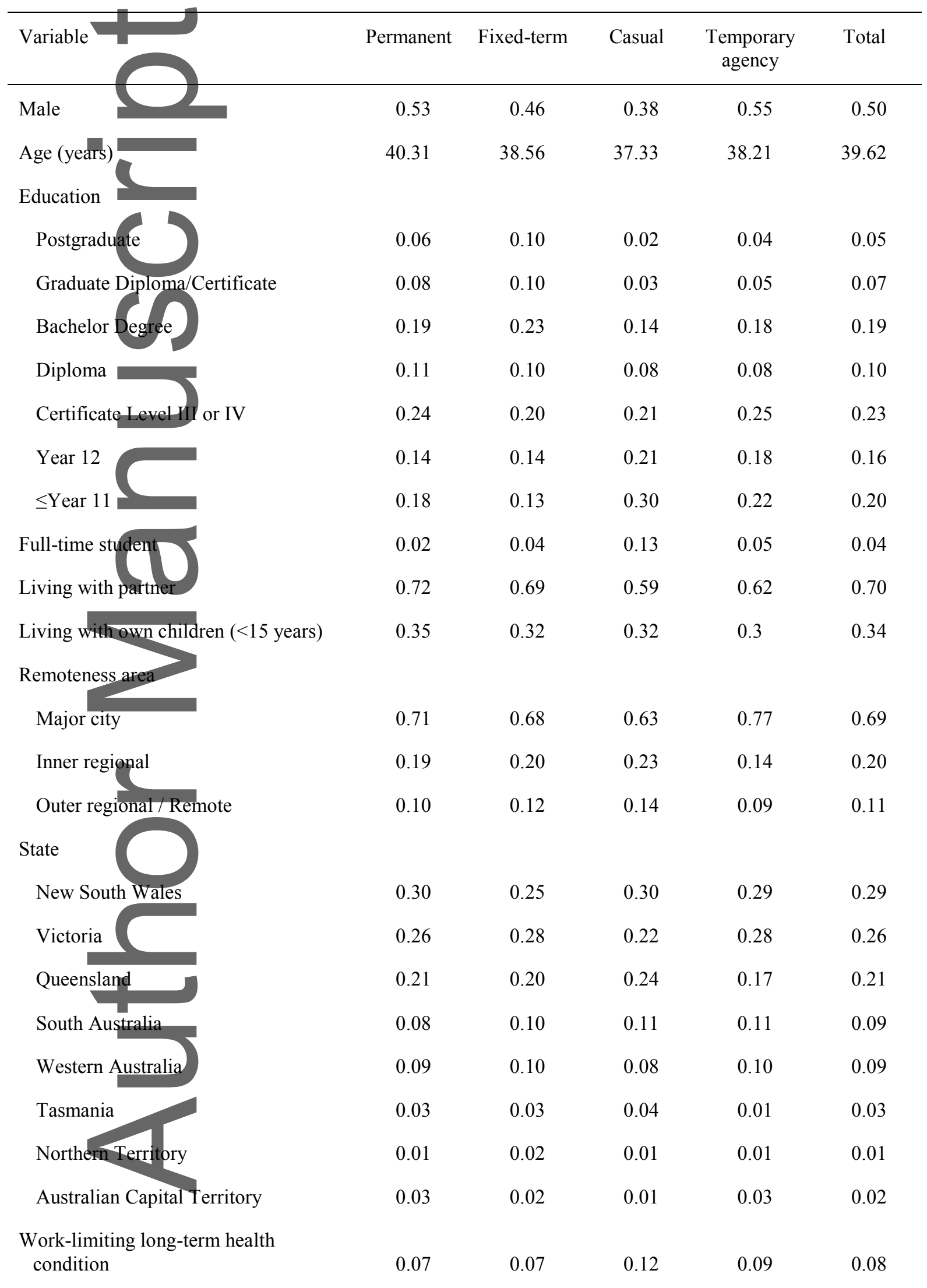




\begin{tabular}{|c|c|c|c|c|c|}
\hline Variable & Permanent & Fixed-term & Casual & $\begin{array}{l}\text { Temporary } \\
\text { agency }\end{array}$ & Total \\
\hline \multicolumn{6}{|l|}{ Origin } \\
\hline Australia - non-Indigenous & 0.78 & 0.78 & 0.79 & 0.69 & 0.78 \\
\hline Australia - Indigenøus & 0.02 & 0.02 & 0.03 & 0.02 & 0.02 \\
\hline $\begin{array}{l}\text { Overseas -main English-speaking } \\
\text { country }\end{array}$ & 0.10 & 0.10 & 0.07 & 0.10 & 0.09 \\
\hline Overseas - oth & 0.11 & 0.10 & 0.11 & 0.19 & 0.11 \\
\hline Job tenure & 7.63 & 4.91 & 3.39 & 2.46 & 6.57 \\
\hline Public sect & 0.29 & 0.42 & 0.16 & 0.15 & 0.28 \\
\hline Supervisor & 0.55 & 0.50 & 0.31 & 0.30 & 0.50 \\
\hline No regular & 0.19 & 0.17 & 0.36 & 0.29 & 0.22 \\
\hline Unemployed within past 12 months & 0.04 & 0.08 & 0.18 & 0.26 & 0.07 \\
\hline $\begin{array}{l}\text { Union / employee association } \\
\text { membership }\end{array}$ & 0.33 & 0.28 & 0.12 & 0.18 & 0.29 \\
\hline \multicolumn{6}{|l|}{ Working hours per week } \\
\hline Part-tim & 0.19 & 0.24 & 0.75 & 0.34 & 0.29 \\
\hline Full-tim & 0.59 & 0.53 & 0.20 & 0.53 & 0.52 \\
\hline Long ho & 0.22 & 0.23 & 0.05 & 0.14 & 0.19 \\
\hline \multicolumn{6}{|l|}{ Occupation } \\
\hline Managers & 0.13 & 0.14 & 0.03 & 0.04 & 0.11 \\
\hline Professio & 0.28 & 0.38 & 0.13 & 0.2 & 0.26 \\
\hline ades workers & 0.13 & 0.11 & 0.10 & 0.14 & 0.12 \\
\hline rsonal service & 0.09 & 0.10 & 0.21 & 0.11 & 0.11 \\
\hline administrative service & 0.18 & 0.14 & 0.12 & 0.19 & 0.17 \\
\hline Sales workers & 0.06 & 0.06 & 0.14 & 0.02 & 0.07 \\
\hline Machinery operators and drivers & 0.07 & 0.03 & 0.07 & 0.12 & 0.07 \\
\hline Labourers & 0.06 & 0.04 & 0.19 & 0.17 & 0.08 \\
\hline Agriculture, forestry, fishing & 0.01 & 0.01 & 0.04 & 0.01 & 0.02 \\
\hline Mining & 0.02 & 0.02 & 0.01 & 0.05 & 0.02 \\
\hline
\end{tabular}

This article is protected by copyright. All rights reserved. 


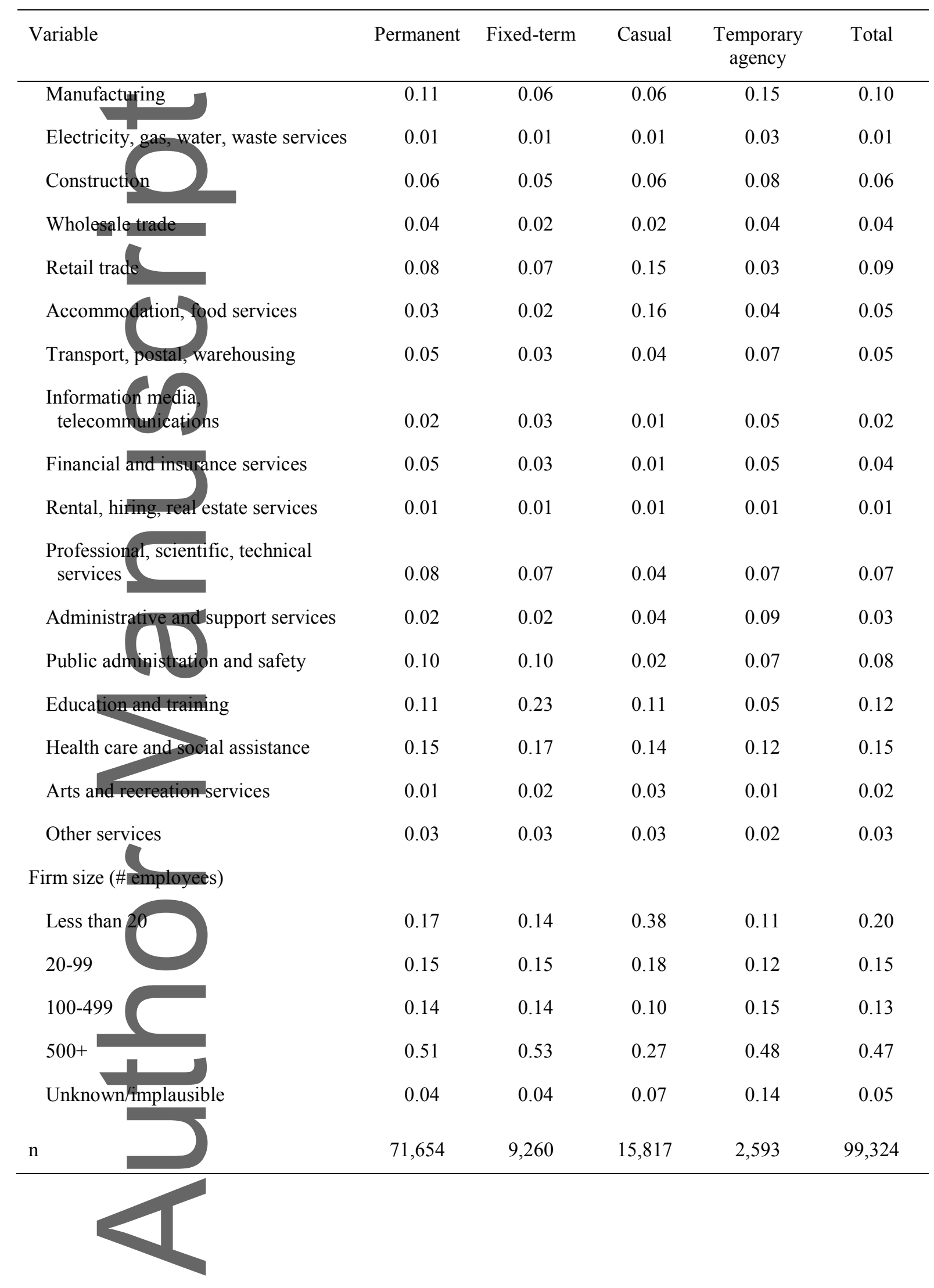

This article is protected by copyright. All rights reserved. 
TABLE 4

Average Pooled Hourly Wage by Employment Type and Gender

\begin{tabular}{lcc}
\hline & Men & Women \\
\hline Hourly wages (\$) & & \\
Permanent employees & 29.78 & 25.56 \\
Fixed-term contract employees & 31.18 & 26.07 \\
Casual employees & 23.31 & 22.59 \\
Temporary agency workers & 31.14 & 26.34 \\
Total & 29.15 & 25.05 \\
Wage differences (\$) & & \\
Permanent vs fixed-term & $-1.41^{*}$ & -0.52 \\
Permanent vs casual & $(2.39)$ & $(1.49)$ \\
Permanent vs temporary agency & $6.47^{* *}$ & $2.97^{* *}$ \\
Fixed-term vs easual & $(15.39)$ & $(10.83)$ \\
Fixed-term vs temporary agency & -1.37 & -0.78 \\
& $(1.21)$ & $(1.07)$ \\
Casual vs temporary agency & $7.88^{* *}$ & $3.48^{* *}$ \\
\hline
\end{tabular}

Cross-sectional responding person weights applied.

Wages are in constant (2008/09) dollars.

Figures in parentheses are absolute values of the t-test of significance of wage differences.

** and *denote statistical significance at the .01 and .05 levels, respectively.

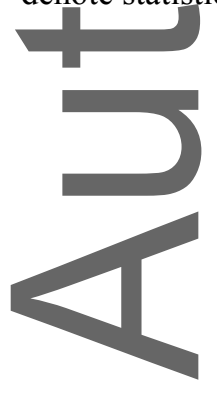


TABLE 5

Temporary Employment and (In) Hourly Wage Gaps:

Comparison of Estimates from Conventional Mean OLS, Mean Fixed-Effects, Conventional UQR and Fixed-Effects UQR Regression

\begin{tabular}{|c|c|c|c|c|c|c|c|c|c|}
\hline & & \multirow[t]{2}{*}{ Mean } & \multicolumn{7}{|c|}{ UQR (percentile) } \\
\hline & & & 5 th & 10th & 25 th & 50 th & 75 th & 90th & 95th \\
\hline $\begin{array}{l}\text { No fixed } \\
\text { effects }\end{array}$ & & $\begin{array}{c}0.04^{* *} \\
-0.03^{* *} \\
0.13^{* *}\end{array}$ & $\begin{array}{l}-0.04^{* *} \\
-0.12^{* *} \\
-0.03\end{array}$ & $\begin{array}{l}-0.00 \\
-0.08^{* *} \\
0.03\end{array}$ & $\begin{array}{c}0.01 \\
-0.04^{* *} \\
0.07^{* *}\end{array}$ & $\begin{array}{c}0.02 \\
-0.05^{* *} \\
0.05^{* *}\end{array}$ & $\begin{array}{l}0.07^{\text {** }} \\
-0.00 \\
0.13^{\text {** }}\end{array}$ & $\begin{array}{l}0.10^{* *} \\
0.03^{* *} \\
0.28^{* *}\end{array}$ & $\begin{array}{l}0.11^{\text {** }} \\
0.05^{\text {** }} \\
0.49^{\text {** }}\end{array}$ \\
\hline & & $\begin{array}{l}48575 \\
0.28\end{array}$ & $\begin{array}{l}48575 \\
0.05\end{array}$ & $\begin{array}{c}48575 \\
0.08\end{array}$ & $\begin{array}{l}48575 \\
0.16\end{array}$ & $\begin{array}{l}48575 \\
0.23\end{array}$ & $\begin{array}{l}48575 \\
0.19\end{array}$ & $\begin{array}{c}48575 \\
0.12\end{array}$ & $\begin{array}{c}48575 \\
0.08\end{array}$ \\
\hline $\begin{array}{l}\text { With fixed } \\
\text { effects }\end{array}$ & $\begin{array}{l}\text { Fixed-term } \\
\text { Casual } \\
\text { Temporary }\end{array}$ & $\begin{array}{l}0.01^{*} \\
0.05^{* *} \\
0.10^{* *}\end{array}$ & $\begin{array}{l}-0.04^{*} \\
-0.02 \\
-0.03\end{array}$ & $\begin{array}{l}0.01 \\
0.01 \\
0.03\end{array}$ & $\begin{array}{l}0.01 \\
0.05^{\text {** }} \\
0.06^{\text {** }}\end{array}$ & $\begin{array}{l}0.00 \\
0.03^{* *} \\
0.05^{*}\end{array}$ & $\begin{array}{l}0.03^{* *} \\
0.06^{* *} \\
0.08^{* *}\end{array}$ & $\begin{array}{l}0.05^{* *} \\
0.09^{* *} \\
0.21^{* *}\end{array}$ & $\begin{array}{l}0.06^{*} \\
0.10^{* *} \\
0.39^{* *}\end{array}$ \\
\hline & $\begin{array}{l}N \\
R^{2} \text { (within) } \\
R^{2} \text { (between) } \\
R^{2} \text { (overall) }\end{array}$ & $\begin{array}{l}48584 \\
0.10 \\
0.12 \\
0.12\end{array}$ & $\begin{array}{l}48584 \\
0.02 \\
0.02 \\
0.02\end{array}$ & $\begin{array}{c}48584 \\
0.02 \\
0.00 \\
0.00\end{array}$ & $\begin{array}{c}48584 \\
0.04 \\
0.14 \\
0.10\end{array}$ & $\begin{array}{c}48584 \\
0.06 \\
0.04 \\
0.05\end{array}$ & $\begin{array}{c}48584 \\
0.05 \\
0.04 \\
0.05\end{array}$ & $\begin{array}{c}48584 \\
0.03 \\
0.00 \\
0.01\end{array}$ & $\begin{array}{c}48584 \\
0.02 \\
0.03 \\
0.02\end{array}$ \\
\hline
\end{tabular}

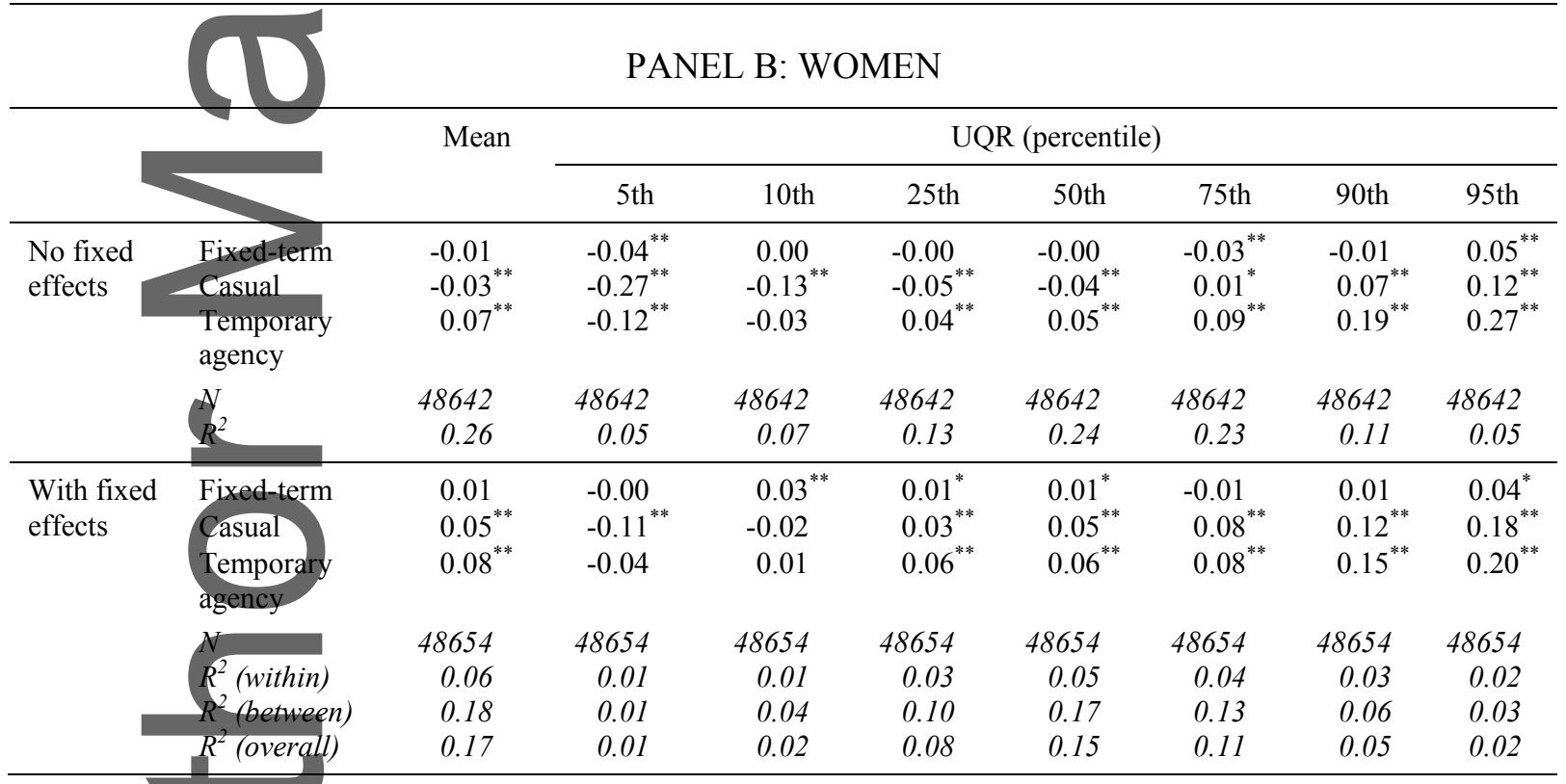

Reference category is permanent employment.

All models include control variables as per specification 1.

Pooled OLS models are estimated with cluster-robust standard errors; mean fixed-effects and conventional UQR models with bootstrapped standard errors; and fixed-effects UQR models with cluster-bootstrapped standard errors.

** and * denote statistical significance at the .01 and .05 levels, respectively.

This article is protected by copyright. All rights reserved. 
FIGURE 1

Temporary Employment and (In) Hourly Wage Gaps of Men (Fixed-Effects UQR)

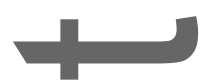

FIGURE 2

Temporary Employment and (In) Hourly Wage Gaps of Women (Fixed-Effects UQR)

FIGURE 3

Density Plot of Men's Wages by Employment Type

FIGURE 4

⿻

Density Plot of Women's Wages by Employment Type

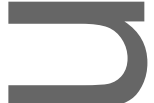

FIGURE 5

Temporancy Employment and (In) Hourly Wage Gaps of Men (Fixed-Effects UQR)

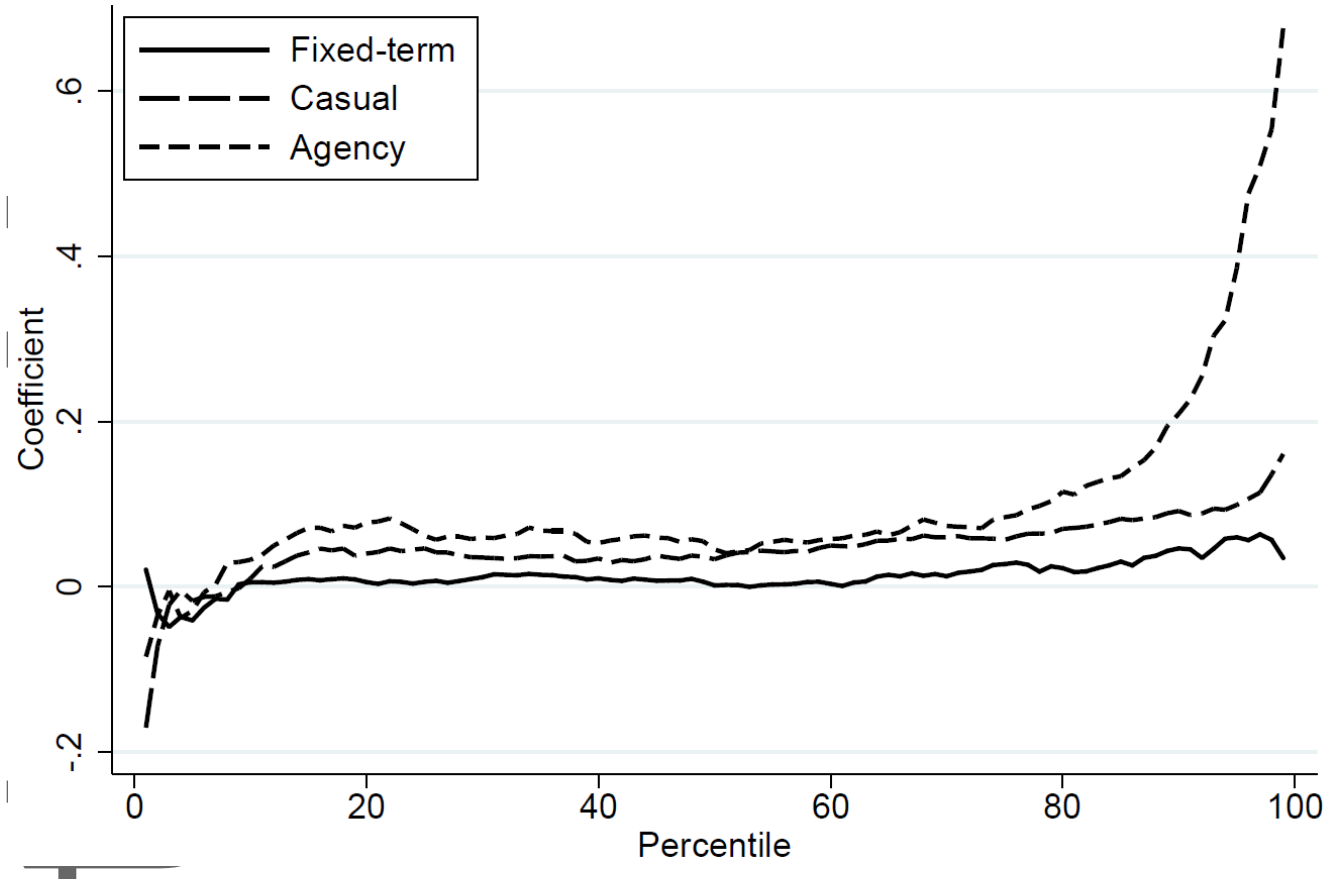

Reference category is permanent employment. Control variables are as per specification 1.

FIGURE 6

Temporary Employment and (In) Hourly Wage Gaps of Women (Fixed-Effects UQR) 


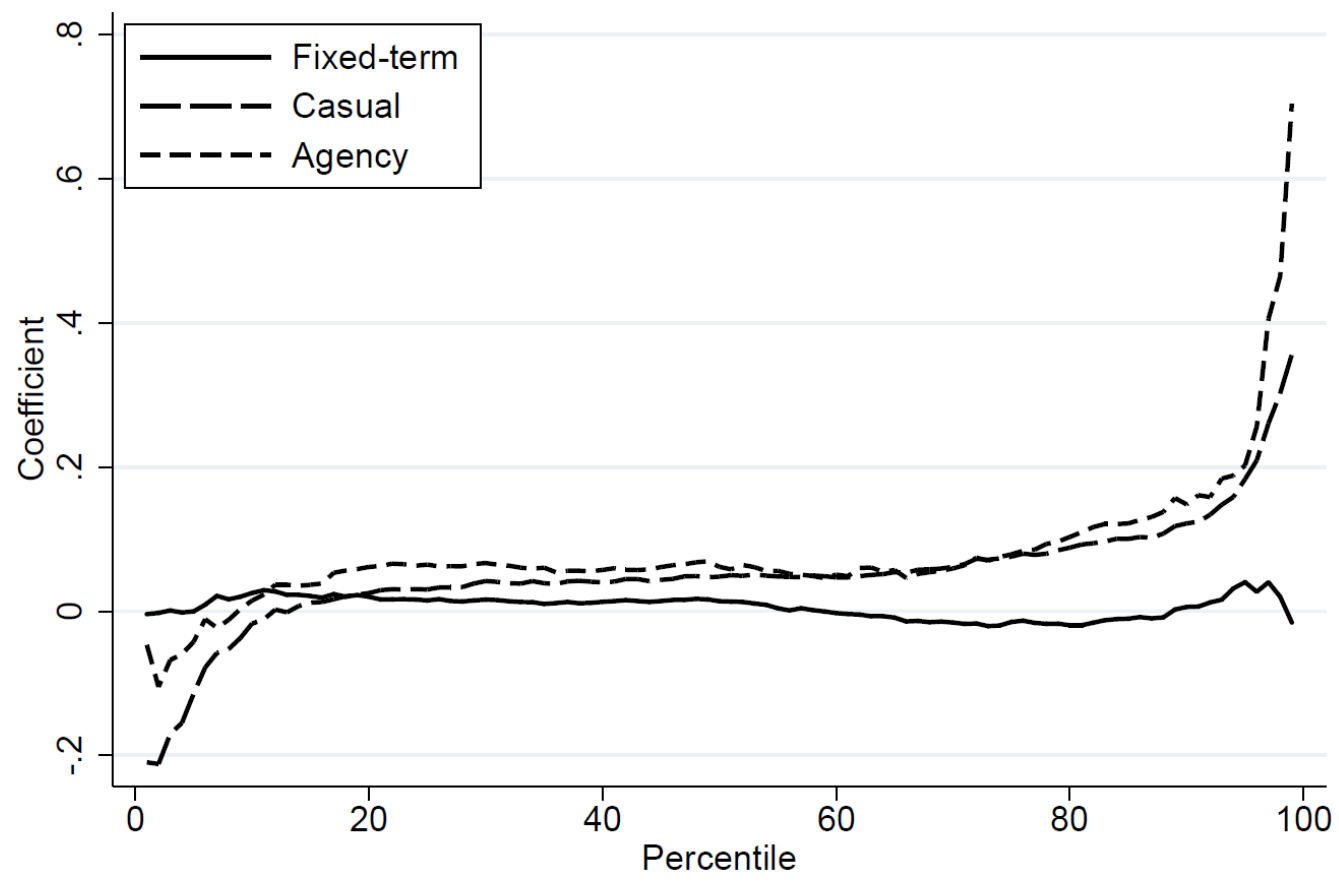

Reference category is permanent employment. Control variables are as per specification 1.

\section{FIGURE 7}

Density Plot of Men's Wages by Employment Type

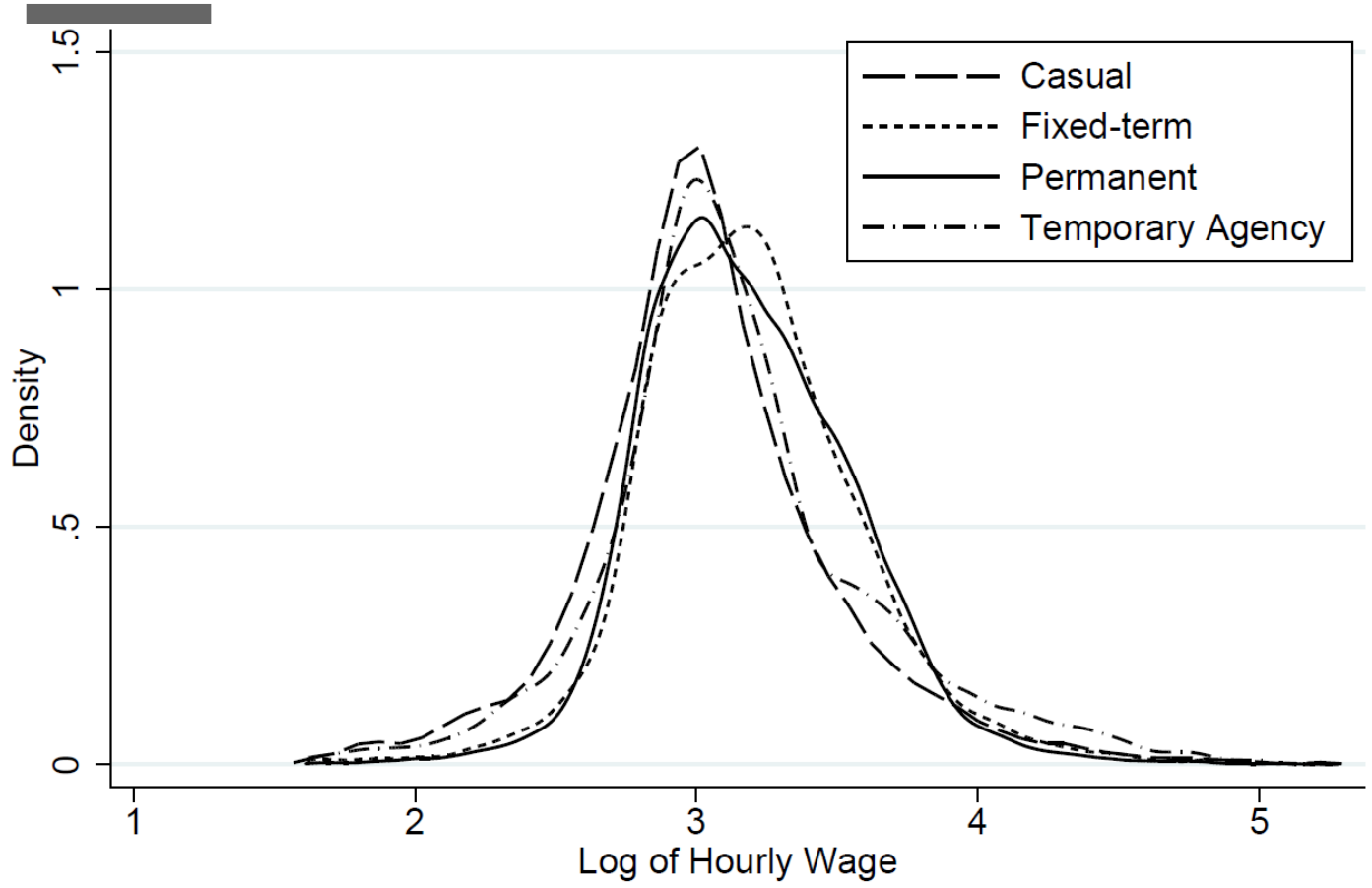

Gaussian kernel, bandwidth $=0.0534$

This article is protected by copyright. All rights reserved. 


\section{FIGURE 8}

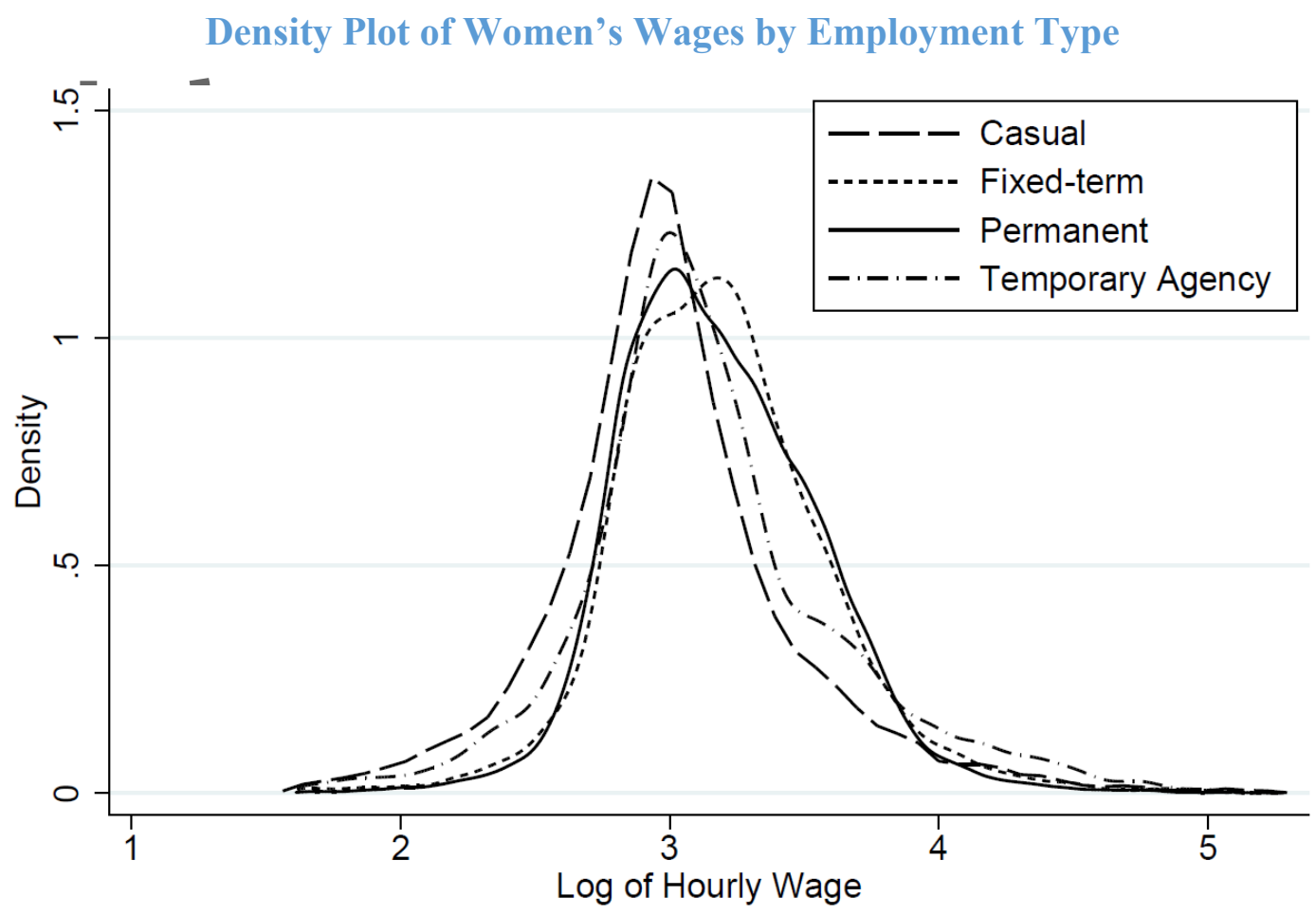

Gaussian kernel, bandwidth $=0.0463$
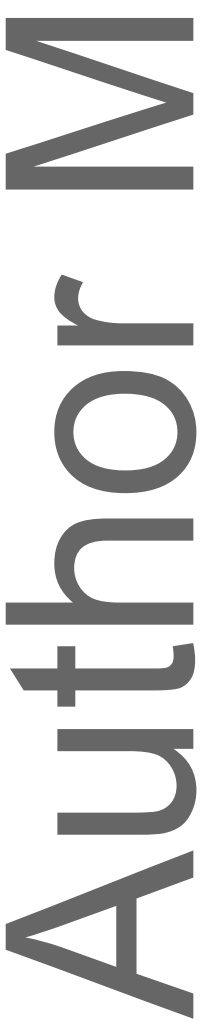


\section{University Library}

\section{- M M N E R VA A gateway to Melbourne's research publications}

Minerva Access is the Institutional Repository of The University of Melbourne

Author/s:

Laß, I;Wooden, M

Title:

The Structure of the Wage Gap for Temporary Workers: Evidence from Australian Panel Data

Date:

2019-01-01

Citation:

Laß, I. \& Wooden, M. (2019). The Structure of the Wage Gap for Temporary Workers:

Evidence from Australian Panel Data. British Journal of Industrial Relations, 57 (3),

pp.453-478. https://doi.org/10.1111/bjir.12458.

Persistent Link:

http://hdl.handle.net/11343/286804 